\title{
LAERE
}

MIDDEL ODK

\section{The quality of quality}

By Thomas Illum Hansen, UCL Erhvervsakademi og Professionshøjskole

Korrekt citering af denne artikel efter APA-systemet (American Psychological Association System, 7th Edition): Hansen, T. I. (2020). The quality of quality. Learning Tech - Tidsskrift for læremidler, didaktik og teknologi, (8), 40-61. DOI 10.7146/lt.v5i8.120896 


\section{Abstract}

Forestillingen om gode læremidler er en abstraktion. Læremidler har egenskaber, der er gode for noget og for nogen, samtidig med, at de er mindre gode for andet og andre. Det afhænger af den situations- og kontekstbestemte interaktion mellem konkrete tegn, aktører og materialiteter. Hensigten med denne artikel er at sætte fokus på den basale normativitet i design, brug af og forskning i læremidler som et privilegeret eksempel på, hvordan man kan forstå komplekse processer i undervisningen. Udgangspunktet er, at forskning i læremidler er særligt velegnet til at sætte fokus på kvalitet i undervisningen; en kvalitet, der i denne sammenhæng bliver udfoldet og forklaret ud fra en teori om tegn. Denne tegnteori bliver eksemplificeret gennem en analyse af repræsentationsproblemet i undervisningen, en flerdimensional teori om kvalitet, en skitse til et sprog om kvalitet i læremidler samt analyser af kvalitet i to prisvindende læremidler.

The concept of "good learning materials" is an abstraction. Learning materials are always good for something and someone, and less good for other things and other people, depending on the situated interaction between actors and materials. This article attempts to frame and understand the basic normativity in the design, use and research of learning materials as a privileged example of how to understand complex and dynamic processes in teaching. The basic assumption is that research into learning materials enjoys a certain prerogative as the focal point for a study of quality in teaching that this analysis will elaborate as a semiotics of quality. This semiotics of quality will be elaborated and exemplified through: an analysis of the problem of representation in teaching; a multidimensional quality theory; a sketch of a meta-language on quality in learning materials; and finally an analysis of the quality of two sets of paradigmatic learning materials. 


\section{The quality of quality}

\section{Toward a semiotics of quality in learning materials}

\section{Understanding quality}

In public discourse, everyone wants more and better quality for less money. This applies not least to the quality of teaching and the quality of textbooks and learning materials because of the political importance we attach to the education of children and young people. However, what is quality? It is a slippery word. An initial and tentative understanding of a widespread discourse on qualities of textbooks can be illustrated with an episode from The Simpsons. Sometimes the animated sitcom gives the teachers of Springfield Elementary School too hard a time.

In one thought-provoking episode, Lisa has trouble answering a question posed by her teacher, Miss Hoover: "What 19th century figure was named 'Old Hickory'?”. Therefore, Miss Hoover reads from the teacher edition of the textbook but she accidentally reads the wrong line: "The Battle of New Orleans". As people with insight in American history will know, the answer is Andrew Jackson.

The teacher's reliance on the textbook becomes too much for Lisa. She takes control of the situation and decides to hide the teacher edition of all the school textbooks in her locker. It causes panic in the teacher's staffroom at Springfield Elementary School. "What do we do?" cries one teacher. "Declare a snow day!" cries another. In the classroom, Miss Hoover is helpless without her teacher edition of the textbook.

Of course, The Simpsons is not evidence, but it is an illustrative reflection of a stereotype that tells us something about the general perception of textbook qualities. The quality of teaching depends on both the quality of the learning materials and the quality of the teachers' use of the learning materials. Lisa and Miss Hoover clearly do not agree on the role and qualities of textbooks. That's an important point. Different actors have different perspectives on what counts as quality. 
This point serves the purpose of framing the very basic research question that structures the theoretical study presented in this article. What is the basis for perceiving the quality of quality in an educational context? In order to analyze and explore what counts as quality, the quality of quality, this article will develop two theoretical frameworks intended to complement each other: first a phenomenology of quality, and then a semiotics of quality.

\section{Phenomenology of quality}

How is it possible to understand what constitutes quality? To do this, we need to develop and apply a phenomenology of quality that is embodied and grounded in the lifeworld. The preliminary claim is that quality becomes alien to us if we only understand it from what counts in a systems world. A prior understanding of this phenomenological perspective can be illustrated and explained by a somewhat critical quote from a Danish poet, Per Højholt, who was asked about his opinion on 'teaching materials' back in 1985:

99 Teaching materials promote intentionally stressful teaching; they are devoid of imagination, unambiguous, inept and over-pedagogical in their helplessness. Teaching might possibly be better in relation to a subject or theme, but if the school is meant to teach for life - then poverty will be just around the corner! The teaching materials take over, replacing or extending the senses, which the students are bound to experience as artificial and alienating [...]. Many modern teaching materials have, as far as I am aware, the side effect that they stand between teacher and student, and often between the content and the student. You learn, but you do not experience, you do not sense.

(Højholt, 1985, my translation)

This Danish poet eloquently expresses what happens to teaching and learning materials if we focus unilaterally and instrumentally on efficiency and learning outcomes. This instrumentalization can be understood within a broader context by virtue of Gert Biesta's analysis of the learning discourse that has become dominant since Højholt's statement (Biesta, 2015). Biesta sharpens the critical eye for a pervasive technocratic approach to educational learning in which a learning discourse is used to reduce and 
downscale all the complexities of education to a simple question of learning. Biesta's term for this discursive development is 'learnification' (Biesta, 2015, p. 75): a degenerate form that is focused on pure exterior performance and emptied of phenomenological presence, purpose and intersubjectivity. The result is that the form of instrumentalization that Højholt criticized is reinforced and sanctioned by a learning discourse that prioritizes the qualities in teaching that are easy to measure, standardize and put into a system.

Biesta is concerned with the general implications of learnification, especially the negative consequences of the core problem that the language of learning undermines the language of education. This article is more concerned with the specific implications from a phenomenological and a semiotic perspective.

Phenomenology is a philosophical approach that is constantly in dialogue with itself because it insists on understanding phenomena through a systematic exploration and description of appearances from a first-person perspective. By applying a phenomenological first-person perspective, we can add another negative effect on substantive learning and depth of understanding. Thus, learnification can also be perceived as a fallacy that forgets and displaces the experience of quality, and thereby empties the concept of quality for qualitative content, because the conceptual understanding of quality is not rooted in a subjectively experienced quality dimension.

\section{Quality of $1^{\text {st }}$ order - experienced quality}

How this is to be understood more precisely, I will elaborate in the following, using an analytical framework in which I distinguish between quality of the $1^{\text {st }}, 2^{\text {nd }}$ and $3^{\text {rd }}$ orders. I have developed this framework in an educational context in order to analyze quality in teaching and learning materials, but as it should emerge, this is a more general theory that is indebted to insights from both the phenomenological and semiotic traditions.

The primordial level of quality in this framework is a $1^{\text {st }}$ order quality that consists of phenomenological qualia and the qualities of the experienced phenomena. It should be emphasized, however, that phenomenology does not explore qualia understood as individual, empirical data in the individual psyche (Zahavi, 2005). Phenomenology is not an introspective psychology, but a systematic exploration of intersubjectively accessible 
qualities and structures that can neither be reduced to internal mental states nor external physical stimuli:

99

There are two ways of being mistaken about quality: one is to make it into an element of consciousness, when in fact it is an object for consciousness, to treat it as an incommunicable impression, whereas it always has a meaning; the other is to think that this meaning and this object, at the level of quality, are fully developed and determinate. (Merleau-Ponty, 2002, p. 4)

In Phenomenology of Perception (1945) Merleau-Ponty elaborates his analysis of experienced qualities. They form a non-reducible starting point for an exploration of the relation between qualities, sensitivity and the embodied cognition:

99 The pure quale would be given to us only if the world were a spectacle and one's own body a mechanism with which some impartial mind made itself acquainted. Sense experience, on the other hand, invests the quality with vital value, grasping it first in its meaning for us, for that heavy mass which is our body, whence it comes about that it always involves a reference to the body.,

(Merleau-Ponty, 1945/2002, p. 46)

Sensations are neither pure reception of external qualities in the world nor the projection of inner mental qualities. On the contrary, they are part of an embodied experience that is intersubjective, but also characterized by a unique subjectivity, which is often expressed with questions of sensory qualia - what it is like to smell a rose, to feel pain at its thorns, to sense its red color etc.

Interestingly, the phenomenological approach to this subjective dimension of quality is congenial with what Charles Sanders Peirce, the founder of semiotics, also termed "firstness" and the feeling of "le tout ensemble" (Peirce, 1994, p. 42). Firstness is the primordial experience of shapes, colors, patterns, configurations (as gestalts and unified wholeness) and perceptive and affective states (moods) in the perceiving subject. For example, music can be physically described as waves, but the experience of the very 
stimulus we call music is a phenomenological qualia and firstness.

Firstness and $1^{\text {st }}$ order quality are essential because they contribute to an experience of grounding and meaningfulness that is not simply defined by external circumstances. When we experience colors and shapes, we experience them as infinitely specific and difficult to describe adequately and comprehensively with linguistic concepts (Ingarden, 1931, § 38; Husserl, 1938, § 59 ). They are characterized by a concrete singularity and deictic "thisness".

In teaching, firstness is the aesthetic and phenomenological basis for learning. It is the rhythm, atmosphere, resonance, sensibility and opportunity to sense and experience phenomena in teaching. I hereby apply Peirce's and Dewey's broad concept of aesthetics (Dewey, 1934). An example of an aesthetic experience can thus be the enriching exploration of a biotope, a holistic experience of an exchange of opinion or the overwhelming, satisfying and fulfilling experience of solving a problem and reaching a solution in mathematics. The point is that students must have the opportunity to experience concrete phenomena in education that have a sensible and meaningful surplus in relation to our experimental ways of describing, exploring and understanding them. They are therefore a source of polysemantic openness in teaching that stimulates curiosity and arouses the interest in cognition.

\section{$2^{\text {nd }}$ and $3^{\text {rd }}$ order quality - reflection and generalization}

$2^{\text {nd }}$ order quality is quality that makes a difference to the subject. Merleau-Ponty's philosophy of embodiment has the consequence that $1^{\text {st }}$ and $2^{\text {nd }}$ order quality must always already be intertwined in perception. According to Merleau-Ponty, perception is already stylized, habitualized and characterized by valorizations. Although I share this view, I maintain a distinction for analytical reasons. By shifting the focus to $2^{\text {nd }}$ order quality, we place emphasis on the valuation and meaning attribution that implies that some qualities in the world are more important to the subject than others. Different colors, shapes and other characteristics are more or less appreciated and appropriate because they are more or less suitable for different vital functions and social purposes. $3^{\text {rd }}$ order quality is the type of quality that typically counts in textbooks. It is generalized and standardized qualities that are weighted at the expense of firstness and $1^{\text {st }}$ order quality. 
$2^{\text {nd }}$ and $3^{\text {rd }}$ order quality together constitute the ways in which we objectify quality and attribute extra meanings to first-order qualities, both in relation to the subject (what matters to me) and socially in relation to different social domains (what counts and attributes value). They are continually negotiated socially, they are subject to conflicts of interest, they are passed on to others by virtue of traditions, and they have far-reaching influence on others through socialization and power relations.

Sociologists such as Bernstein (1996, 1999 \& 2001) and Bourdieu (1998) have argued convincingly that the most important societal focal point for the distribution and sedimentation of qualities is general education in schools and colleges. The question is to what extent we manage to involve students in the social negotiation. Do we frame and design action potentials and dispositions that allow them to experience, explore and relate to $1^{\text {st }}$ order qualities themselves? Learnification is precisely a form of educational degeneration because we too often create learning activities where quality is given in advance as $2^{\text {nd }}$ and $3^{\text {rd }}$ order qualities.

\section{Amplify Science}

The American learning material, Amplify Science, is an interesting example of the fact that phenomenological $1^{\text {st }}$ order quality is crucial to the quality of the learning material. Amplify Science is relevant for several reasons. It is based on research and developed by the Lawrence Hall of Science at the University of California, Berkeley. It is phenomena based, and it is top rated by EdReports, an independent nonprofit organization of educators, for educators, designed to improve K-12 education in the United States.

EdReport's evaluations are conducted as desk research. They do not have empirical data on the experienced quality, but assess the quality at a distance based on standardized qualities with three main gateways, underlying criteria and indicators. The criteria for qualities are given with NGSS, the Next Generation Science Standards, and they are K-12 science content standards. Standards set the expectations for what students should know and be able to do. The NGSS were developed by states to improve science education for all students.

The two main criteria in the evaluation highlight a three-dimensional theory of learning that puts problems and phenomena 
at the center. The underlying rubrics with indicators support how to evaluate the different dimensions and qualities of the learning materials.

Figure 1.

Criteria for evaluation of learning materials based on NGSS.

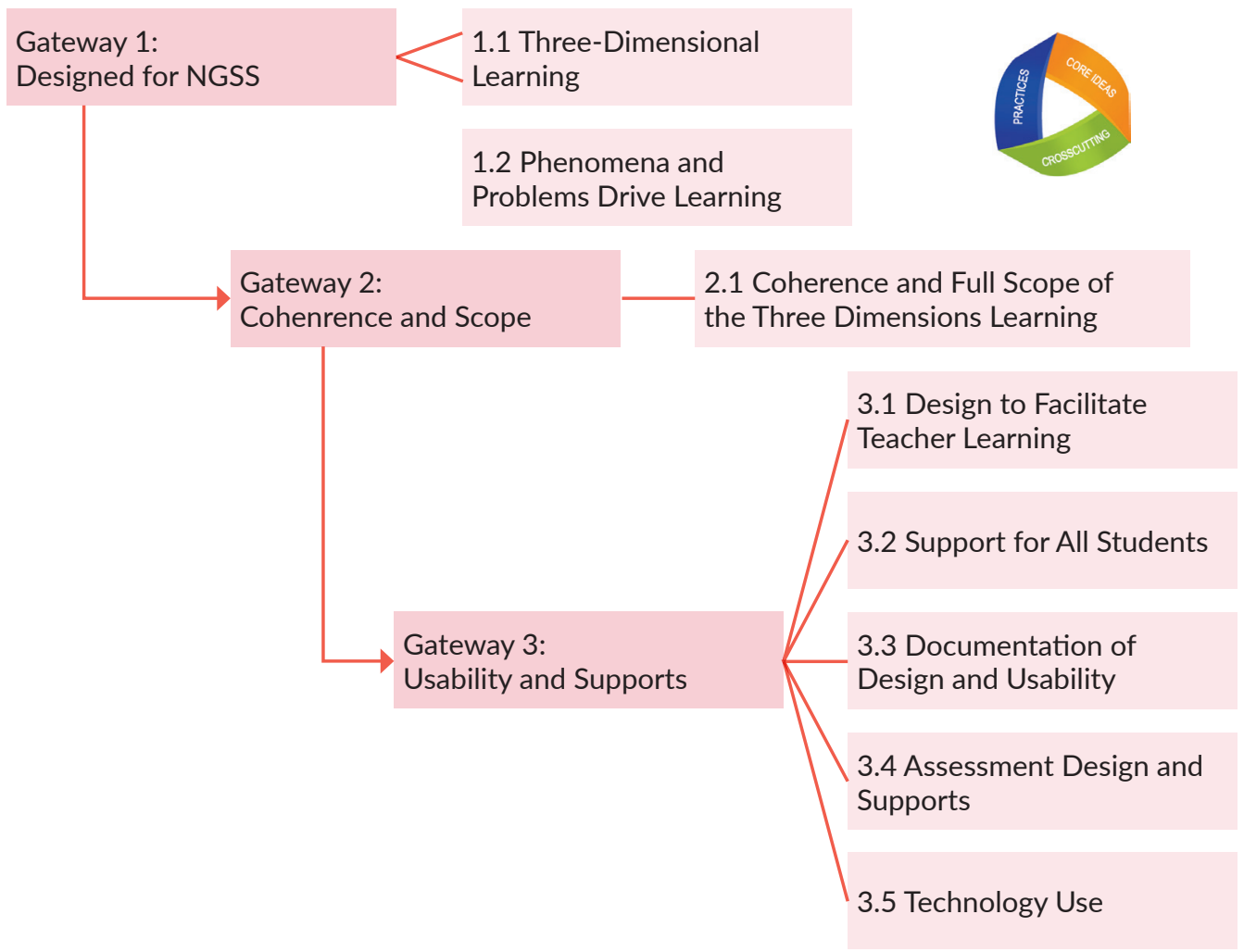

Let's take a closer look at an example, Rock Transformations, that emphasizes the importance of phenomena in the evaluation of Amplify Science.

Students are presented with the phenomenon concerning how the rocks of the Rocky Mountains and the rock of the Great Plains have a similar mineral composition. In Chapter 1: Rock Formations, students interact with this phenomenon as directly as possible by watching a video, interacting with a digital simulation, and engaging in a hands-on investigation to explore processes leading to the formation of rocks that cannot be observed first-hand. 
Thus, it is the multimodal representation in Amplify Science that scaffolds access to the phenomena as directly as possible. In order to illustrate I would like to highlight some essential qualities.

\section{Qualities of Amplify Science}

Amplify Science is, according to the authors, designed on the basis of a research-based, multimodal pedagogy that combines different semiotic modes. Of particular interest are the shifts between semiotic modes scaffolding students' inquiries. With reference to Gunther Kress (2000) and Denise Newfield (2009), I would describe it more aptly as "transductions" or "transmodal moments" - scaffolding a guided discovery as shown in Figure 2:

\section{Figure 2.}

Transduction as transmodal moments in

Amplify Science.

Research-based, multimodal pedagogy

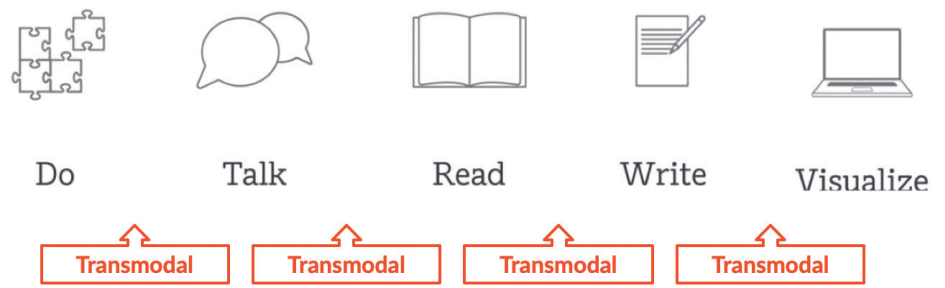

Multimodal scaffolding is important for access to evidence from multiple sources in Amplify Science that allow students to explore phenomena themselves, be engaged in problem solving and construct meaning across the sources:

- Hands-on-materials are crucial for the embodiment and the student's concrete experiences with the phenomena. It may be, for example, materials that give students a tactile and kinesthetic experience of friction.

- Structured argumentation activities scaffold group work and exploratory talks that link to evidence from multiple sources. 
— Digital simulations make it possible to represent and experiment with qualities and relations that cannot be immediately perceived.

- Digital problem-posing simulates real world problems that are designed to include appropriate proportions of phenomena and problems, for example to design a portable baby incubator that uses phase change materials that meet three criteria: keep the baby's average temperature as close to 37 degrees Celsius, minimize the time the baby spends outside of the healthy temperature range, and keep costs low.

The didactic design for teaching and learning in Amplify Science can be characterized as a matrix that combines phenomenon-based in-depth knowledge and problem-based linking to the real world outside the school.

Although Amplify Science has obvious qualities, it also exhibits a didactic double bind in terms of the quality of learning materials. It seems valid and substantiated that Amplify Science is top rated by EdReports, when assessing it based on desk research. However, $1^{\text {st }}$ order qualities are experienced in situations as part of a particular context that EdReports has not investigated empirically. Amplify Science valorizes specific phenomena and problems that emphasize the importance of experiencing $1^{\text {st }}$ order qualities, but didactically this is a learning material that attempts to standardize the unique experience of $1^{\text {st }}$ order quality with reference to NGSS's $3^{\text {rd }}$ order standardization of qualities. This raises several critical questions that focus on implied contradictions.

Amplify Science is characterized by guided discovery, but what about open-ended inquiries that frame a polysemantic experience of $1^{\text {st }}$ order qualities? Amplify Science is designed as an all-inclusive system, but what about diversity of materials? Amplify Science is characterized by a high degree of standardization, but what about the unique quality of learning materials that represent domain-specific content in an original way? These critical issues require qualification and substantiation. Therefore, I want to form a perspective on my critical questions within a larger semiotic context. 


\section{Semiotics of quality}

A semiotics of quality can enlighten the often contradictory demands we make on learning materials. They are expected to be original, innovative, well-tested and of a certain standard. Being a publisher is not easy.

Let me briefly explain the relationship between the phenomenology of quality and the semiotics of quality. The phenomenological approach is used to explain the foundation and therefore emphasizes the quality of $1^{\text {st }}$ order. The semiotic approach is used to explain the discursive context and emphasizes the historical and socio-cultural determination of the quality of $2^{\text {nd }}$ and $3^{\text {rd }}$ order.

The semiotic theory that underlies my approach to learning materials is akin to phenomenology. Therefore, there is no contradiction between the theories, but rather an emphasis on the fact that the semiotic analysis has a phenomenological basis. The primary inspiration is Charles S. Peirce (Peirce, 1903; Peirce, 1998).

The extended focus on the socio-cultural aspect can also be qualified by, for example, Mikhail Bakhtin and Juri Lotman's theories of the semiotic context (Lotman, 2005), but in this context I apply Julian Greimas' semiotic square to frame the semiotic analysis (Greimas \& Rastier, 1968).

Initially, I will make some observations on how quality is treated within different discourses and practices that deal with learning materials. From a semiotic perspective, quality appears at least under four different regimes of meanings (Festi, 2019), which I will try to characterize in the following.

\section{Unique quality}

Unique quality is specific and singular. It is the particular style of a learning material, a specially successful configuration of semiotic resources - text, sounds, pictures and diagrams - that vitalizes and creates potentials for a deep understanding of a phenomena or a problem. It is socio-culturally heterogeneous like an educational "terroir" that is evaluated with thick, qualitative descriptions.

Terroir is a French term used of wine, tea and coffee to express the unique geographical characteristics of the product. The idea is that a piece of land or field is defined by factors such as soil, topography and a particular method of cultivation. These conditions are unique to places around the world and therefore 
have different degrees of influence on the wine. The basic idea is that these conditions are reflected in the final wine in a sophisticated way.

In a related way, unique and sophisticated courses and materials are developed around the world, for example within German Lehrkunstdidaktik. They reflect the very special learning potential in relation to subject-specific phenomena in a certain educational context that are woven into certain sociocultural values and purposes.

\section{Traditional quality}

Traditional quality is normative and praxeological. The quality depends on a praxis settled over time - both in the production and use of learning materials - by repetition, qualifying routines and recognized distinction. It is a historically appreciated practice (reputation and testimonials) trying to replicate and reproduce a particular quality based on norms and guidelines. This is quite a decisive quality in the production of teaching aids. It is crucial for publishers that they can guarantee a high level of quality through a tradition of constantly refining and sophisticating their methods and procedures.

\section{Standardized quality}

Standardized quality is generic and scalable. It is the regulated procedures and reproducible qualities that ensure a certain minimum of quality. It is based on adherence to a system of constrictions, such as standardized curricula and testing. The syntax of the process, visible control and quantification are valued at the expense of content and materiality.

\section{Innovative quality}

Innovative quality is inventive and deconstructive. It is the innovative design or redesign of a learning material, a creative configuration of semiotic resources that reinvent and revitalize teaching and learning. The negation and deformation of traditions and standards is a destructive part of the creative interpretation and redetermination of qualities, amplifying the affordances of design and materiality - and it is often inspired by new knowledge and technological development. 


\section{The semiotic square of quality}

As already suggested, the four discourses are intimately connected. I will analyze the relations between them using a semiotic square of quality.

Unique and standardized quality is a contrarian and incompatible contradiction. A quality cannot be unique and standardized at the same time.

Unique and traditional quality is contradictory. Tradition is to some extent a negation of the unique since the attempt to repeat high quality at the same time makes the quality less unique.

Tradition is, on the other hand, a condition or a prerequisite for the development of standardized quality. The reason is that standardization tries to develop formal procedures based on valued traditions.

Standardized and innovative quality is also contradictory. Innovation is to some extent a negation of standards. Innovation is, on the other hand, a condition or a prerequisite for the development of new unique quality. The reason is that uniqueness is developed in a world with traditions and standards.

\section{Figure 3.}

The semiotic square of quality - production, use and distribution of materials.

The semiotic square of quality - production, use and distribution of materials

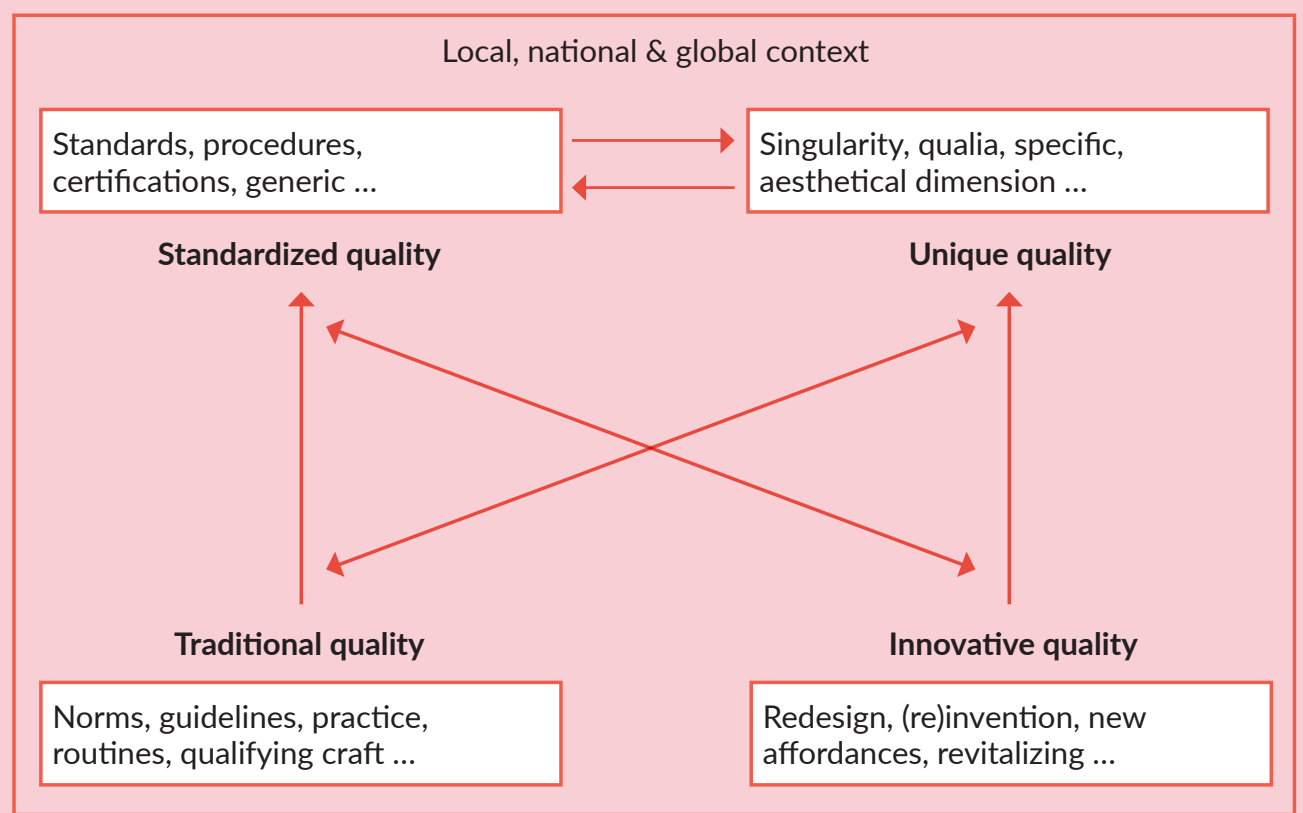


The semiotic square can be used to describe a dynamic development of quality over time from unique to traditional, standardized and innovative quality. This development is influenced by both the local, the national and the global context. There are still national differences in innovation and the production of learning materials, but the OECD in particular, and the widespread use of international comparative studies, have contributed to a global standardization of quality across countries.

Marketing of learning materials shows that they typically want to be everything at once: Innovative, back to the good traditions, kid-tested and typically associated with curricular standards.

Figure 4.

A typical excessive marketing of a learning material.

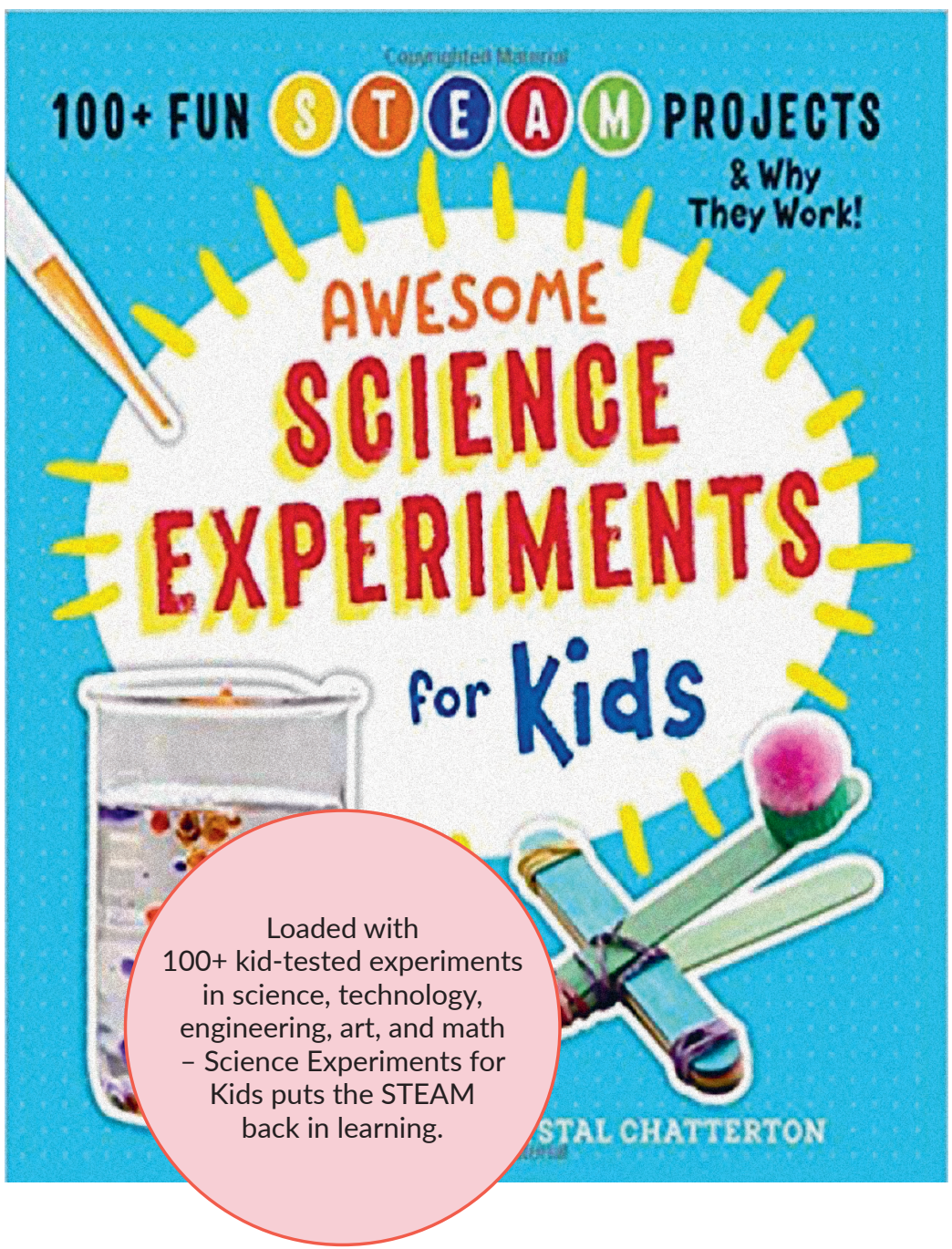


In the following section we will explore a more elaborated example of a prize-winning learning material.

\section{Salto 7A, Learners book}

The Norwegian learning material, Salto, is an interesting example of the fact that the semiotics of quality is crucial to evaluations of learning materials.

Salto 7 A, Learners book is relevant for several reasons. It is a digital textbook for Language Art teaching. It is not phenomena based, unlike Amplify Science, but instead quite formalistic, it has the very special quality that it contains meta-text that introduces the textbook and its genre and structure, and finally it won a prize for the best European learning material awarded by BELMA, CATEGORY 2: Second half of primary education and lower secondary education.

$B E L M A$ is a competition run by three international organizations with a special interest in education and learning materials (The EEPG, European Educational Publishers' Group, The Frankfurt Book Fair and IARTEM).

Unlike Edreports, phenomena based teaching and the representation of content are not central values or evaluation categories in BELMA's evaluations. BELMA upgrades qualities such as clarity, accuracy, instructional objectives, individualization, learner centeredness, metacognition and transferability. Common to them all is that one can interpret them formally and operationalize them instrumentally, because they do not substantially relate to the heterogeneity of phenomena and problems within a subject-specific domain. The categories are what I would call formalistic, because they are suitable for an instrumentalization and standardization that entails an abstraction from the experiential content of the subjects. 
Clarity of aims Do the materials clearly indicate the learning objectives?

Are the skills taught and the target level clearly specified?

Clarity about achievement Do the materials help learners become conscious of success and of weaknesses and inform them about progress made in relation to the learning objectives?

Clarity of presentation Do the materials present a clear and logical structure with appropriate, comprehensible instructions and layout?

Clarity of rationale Do the materials provide the teacher with a methodological rationale, explaining the learning approach(es) used?

Simultaneously BELMA downsizes qualities such as aesthetic experience, expressive objectives, content, otherness, world-centredness, phenomena based inquiries and subject-specific deep understanding. In this context, world-oriented can be understood as a design that perceives the divide between the teacher and learner centredness as a false dilemma. Scaffolding is crucial for students' agency, but it is world-related problems and phenomena that are in focus. Likewise, deep understanding does not refer to a cognitive learning progression in the student's head. Understanding is a relation between the student and problems and phenomena in the world. Carl Bereiter in particular is known for offering a different perspective on depth than a narrow cognitive concept of learning (Bereiter, 2006). According to Bereiter, deep understanding means understanding deep things about subjects worthy of our students' attention. Understanding deep things about the problems and phenomena in question implies deep, persistent and extensive involvement with things that provide resistance.

The interesting thing is that BELM's formalistic priority is clearly expressed in the evaluation of the learning material, which involves an explicit appreciation of very generic and abstract qualities. The BELMA jury emphasizes that "The dual emphasis on reading comprehension and text creation develops highly 
valuable transferable skills that provide important foundations for any learning experience"(https://www.belma-award.eu/).

The text box to the right of the screen is an example of how a chapter is framed with instructional objectives (for example, "After the chapter, you should be able to find the story arc in a narrative") and an explicit focus on generic features (the characteristics of fiction, the building blocks of narratives and general strategies for reading comprehension).

Figure 6.

A formalistic framing of learning activities with focus on generic features.

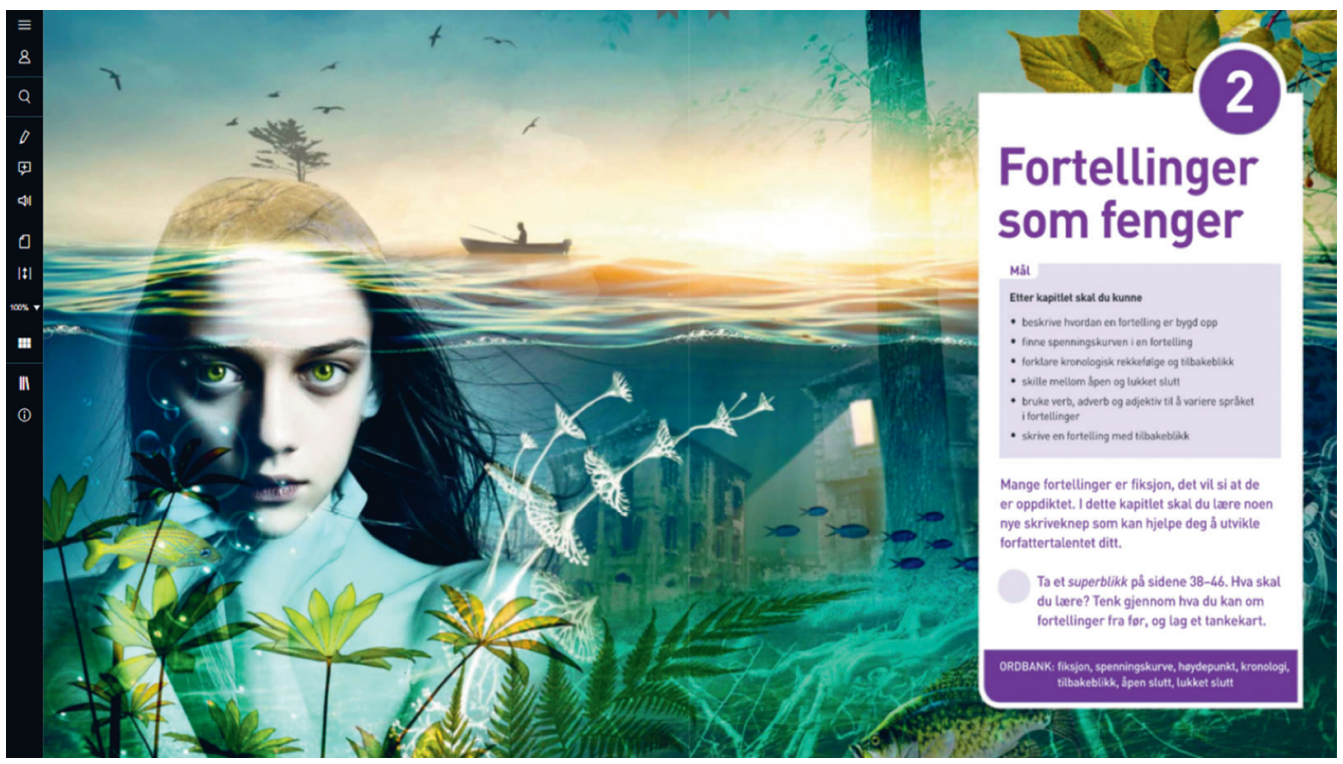

This evaluation reflects the same standardized qualities as OECD, the Organization for Economic Co-operation and Development. Andreas Schleicher, a key member of the OECD Senior Management team and Director for Education and Skills has put it quite clearly: It is more important to learn how to learn than to learn something subject-specific (Schleicher, 2015).

My own analysis of Salto confirms that it is a learning material characterized by generic and standardized qualities. However, I want to point out two things that stand out: the use of questions based on text-interpretation, and the use of text creation. Both contribute to unique and innovative quality, but 
are part of a larger design that is characterized by traditional and standardized qualities.

Salto is, in many ways, a traditional, though well-produced, learning material that meets the highest standards with regard to annotation tools, functional graphics, read aloud functions, and so on.

\section{Figure 7.}

A typical design for digital textbooks with annotation tools, functional graphics, read aloud functions.
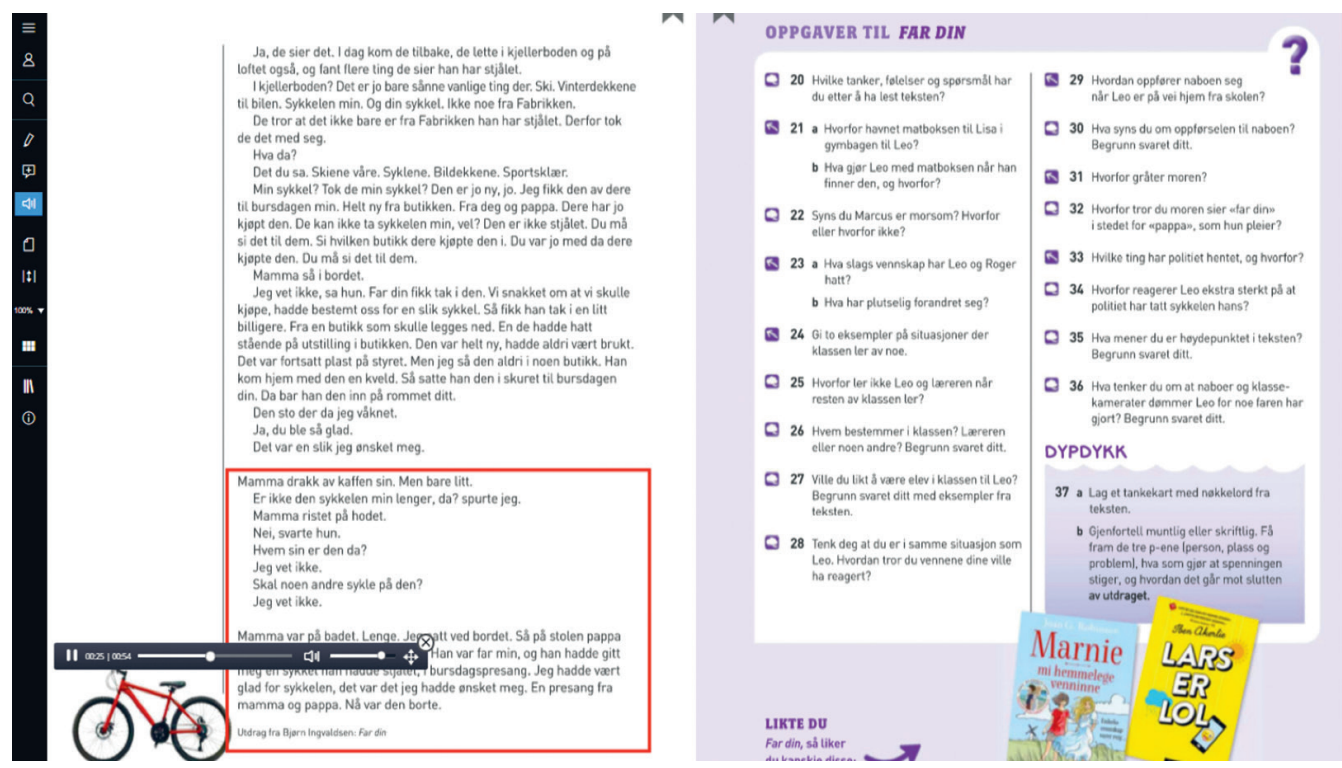

Thus, Salto accommodates to a certain extent a number of traditional and standardized qualities. The problem, however, is that these qualities are not substantiated by research in learning materials and literature teaching. This becomes clear if we evaluate Salto based on a major review covering a total of 216 studies concerning the effects and more widely understood influences of literature (Elf \& Hansen (Ed.), 2017). On the basis of this review, research-based principles for literature teaching and learning materials were formulated, arguing that applying general reading strategies and instructional objectives in literature teaching has negative consequences, because in this way one creates an abstract content in teaching, rather than scaffolding an experience with literary texts as concrete aesthetic phenomena. 
The result is a kind of learnification of literature teaching, where the qualities of teaching are not based on an experience of $1^{\text {st }}$ order qualities in literature as an aesthetic phenomenon, because the conceptual understanding of quality is not rooted in a subjective quality dimension.

\section{Implications for further practice and research}

The focus of the present study was to develop two theoretical frameworks: a phenomenology of quality, and a semiotics of quality that complement each other, in order to contribute to a deeper understanding of the basis for perceiving quality in an educational context and of what counts as quality, the quality of quality.

The specific analyses of the two teaching materials, respectively Amplify Science and Salto, provide concrete insights into how the two frameworks can be used to explore the different types of qualities of the teaching materials. Amplify Science intends to frame a phenomena based exploration and $1^{\text {st }}$ order experiences of qualities in science, while Salto tries instead to focus more directly on $2^{\text {nd }}$ and $3^{\text {rd }}$ order qualities in a teaching situation that emphasizes generic competencies and transferability.

The general reflection on the two approaches to the evaluation of teaching materials, EdReports and BELMA's evaluation categories respectively, indicates that the combination of a phenomenology of quality and a semiotics of quality has a wider scope. This combination can be used to develop the theoretical basis for the evaluation of learning materials, and to inspire the design, production, distribution and use of learning materials. The combination of the two frameworks thus helps us to understand that what we perceive as good learning materials will often be in a field of tension between unique, traditional, standardized and innovative quality.

The combination of the two theoretical frameworks may also have implications for further research. It proposes a combination of qualitative and quantitative methods. On the one hand, we need to gain deeper insight into $1^{\text {st }}$ order qualities in the use of learning materials and phenomenon-based teaching. This requires phenomenological analyses and thick descriptions of how learning materials are actualized in teaching in a first-person perspective. On the other hand, we need more comprehensive analyses of the discursive regimes and the measurement 
of effects, in order to understand the contextual semiosis and causal relation between the characteristics of the learning materials and the qualities that count in the educational system and the surrounding community.

The implications outlined here may help explain why it is so difficult to develop, evaluate and use teaching materials in ways that contribute substantially to the quality of teaching. In particular, the political pressure to prioritize standardized qualities assigns an important role to research in learning materials as a corrective that documents the importance of unique quality and a phenomenological foundation in teaching. Lisa from The Simpsons is therefore probably not going to be the last student to want to hide away the teacher edition of all the school textbooks in her locker.

\section{References}

Barron, B., Schwartz, D., Vye, N., Moore, A., Petrosino, A., Zech, L., Bransford, J. \& The Cognition and Technology Group at Vanderbilt. (1998). Doing with understanding: Lessons from research on problem- and project-based learning. The Journal of the Learning Sciences, 7(3/4), 271-311.

Bereiter, C. (2006). Reflections on Depth. In K. Leithwood, P. McAdie, N. Bascia \& A. Rodrigue (ed.), Teaching for Deep Understanding: What Every Educator Should Know. Thousand Oaks: Corwin Press.

Bernstein, B. (1996). Pedagogy, Symbolic Control and Identity: Theory, Research, Critique. London: Taylor and Francis.

Bernstein, B. (1999). Official knowledge and pedagogic identities. In F. Christie (ed.), Pedagogy and the Shaping of Consciousness. London: Continuum.

Bernstein, B. (2001). From pedagogies to knowledges. In A. Morais, I. Neves, B. Davies \& H. Daniels (eds.), Towards a Sociology of Pedagogy. New York: Peter Lang Publishing.

Biesta, G. (2015). What is education for? On good education, teacher judgment, and educational professionalism. European Journal of Education, 50(1), 75-87.

Bourdieu, P. (1998). Practical Reason: On the Theory of Action. Stanford, CA: Stanford University Press.

Chang, A.-M., Aeschbach, D., Duffya, J. F. \& Czeislera, C. A. (2014). Evening use of light-emitting eReaders negatively affects sleep, circadian timing, and next-morning alertness. PNAS, 112(4), 1232-1237. DOI: 10.1073/ pnas.1418490112

Cuban, L. (1984). How teachers taught. Constancy and Change in American Classrooms, 1890-1980. New York: Longman.

Dewey, J. (1910). Science as Subject-Matter and as Method. Science, 31(787), 121-127. 
Elf, N. \& Hansen, T. I. (2016). Hvad vi ved om undersøgelsesorienteret undervisning i dansk: Og hvordan vi kan bruge denne viden til at skabe bedre kvalitet $i$ danskfagets litteraturundervisning i grundskolen: Forundersøgelse i projekt Kvalitet i Dansk og Matematik, delrapport 2. [What we know about inquiry-based teaching in Danish Language arts: And how we can use this knowledge to promote quality in the Danish Language arts' literary education in primary school: Preliminary study in project Quality in Danish and Mathematics, sub-report 2]. København: Undervisningsministeriet.

Festi, G. (2019). Toward a Semiotics of Food Quality: Perspectives and Interpretative Challenges. Milano: Nuova Accademia di Belle Arti. DOI: 10.24308/iass-2014-097

Gardner, H. \& Davis, K. (2014). The App Generation. How Today's Youth Navigate Identity, Intimacy, and Imagination in a Digital World. New Haven \& London: Yale University Press.

Greimas, A. J. \& Rastier, F. (1968). The Interaction of Semiotic Constraints, Yale French Studies, 41, 86-105.

Hansen, T. I., Elf, N. F., Gissel, S. T. \& Steffensen, T. (2019a). Designing and testing a new concept for inquiry-based literature teaching: Design principles, development and adaptation of a large-scale intervention study in Denmark. L1-Educational Studies in Language and Literature, 19, 1-32. https://doi.org/DOI: 10.17239/L1ESLL-2019.19.04.03

Hansen, T. I., Elf, N. F., Misfeldt, M., Gissel, S. T. \& Lindhardt, B. K. (2019b). KVALITET I DANSK OG MATEMATIK: Et lodtrcekningsfors $\emptyset$ med fokus på undersøgelsesorienteret dansk- og matematikundervisning [QUALITY IN DANISH AND MATHEMATICS: A RCT effect study focusing on inquirybased Danish and mathematics education] (1. ed.). Odense: Læremiddel.dk.

Højholt, P. (1985). Midlernes magt. KvaN 12.

Kirschner, P. \& Clarck, R. E. (2006). Why Minimal Guidance During Instruction Does Not Work: An Analysis of the Failure of Constructivist, Discovery, Problem-Based, Experiential, and Inquiry-Based Teaching. Educational Psychologist, 41(2), 75-86.

Merleau-Ponty, M. (2002). Phenomenology of Perception. London: Routledge. National Research Council. (2012). A Framework for K-12 Science Education: Practices, Crosscutting Concepts, and Core Ideas. Washington, DC: The National Academies Press. https://doi.org/10.17226/13165.

Peirce, C. S. (1994). Charles Sanders Peirce-Semiotik og pragmatisme. København: Samlerens Bogklub.

Peirce, C. S. (1903). On Phenomenology. In N. Houser \& C. J.W. Kloesel (eds.,1998), The Essential Peirce. Selected Philosophical Writings. Vol. 2 (1893 - 1913), 145-159. Bloomington and Indianapolis: Indiana University

Peirce, C. S. (1998, originally published in 1931-58). Collected Papers of Charles Sanders Peirce, Volumes IVIII, (ed. by C. Hartshorne, P. Weiss, A. Burks). London: Thoemmes Press.

Schleicher, A. (2015). Prologue. In C. Fadel, B. Trilling \& M. Bialik, FourDimensional Education. The Competencies Learners Need to Succeed. Boston, MA: Center for Curriculum Redesign.

Zahavi, D. (2005). Subjectivity and selfhood: Investigating the first-person perspective. Cambridge, Massachusetts: MIT Press. 


\section{Learning Tech - Tidsskrift for læremidler, didaktik og teknologi Udgives af Læremiddel.dk}

Learning Tech er et forskningstidsskrift, hvor alle artikler er forskerbedømt i form af dobbeltblindt peer review. Tidsskriftet bringer artikler, der rammer genstandsfeltet mellem læremidler, didaktik og teknologi, og hensigten er at spille en betydelig rolle som platform for den voksende skandinaviske læremiddelforskning.

\section{Redaktion}

Stig Toke Gissel, UCL Erhvervsakademi og Professionshøjskole (ansvarshavende redaktør)

Bettina Buch, Professionshøjskolen Absalon

Hildegunn Juulsgaard Johannesen, University College Syd

Ove Christensen, Professionshøjskolen Absalon

René Boyer Christiansen, Professionshøjskolen Absalon

Thomas R.S. Albrechtsen, University College Syd

\section{Redaktionssekretær}

Trine Ellegaard, UCL Erhvervsakademi og Professionshøjskole

\section{Temaredaktion}

Stig Toke Gissel, UCL Erhvervsakademi og Professionshøjskole Thomas R.S. Albrechtsen, University College Syd

\section{Design og grafisk tilrettelæggelse}

Trefold - grafisk design og kommunikation

\section{Tryk}

Narayana Press, Gylling

ISSN 2445-7981 (Tryk)

ISSN 24.45-6810 (Online)

\section{Rettigheder}

(C) 2020 Læremiddel.dk og forfatterne

\section{Kontakt}

Læremiddel.dk, Niels Bohrs Allé 1, 5230 Odense M www.laeremiddel.dk

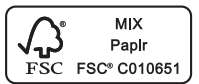

